\title{
EMANSIPASI WANITA DALAM NOVEL AKU LUPA BAHWA AKU PEREMPUAN KARYA IHSAN ABDUL QUDDUS
}

\author{
Lily Alvionita Maksum ${ }^{1}$, Sance A. Lamusu² ${ }^{2}$ Herman Didipu ${ }^{3}$.
}

\section{Info Artikel}

Sejarah Artikel:

Diterima Februari 2021

Disetujui Maret 2021

Dipublikasikan Mei 2021

\section{ABSTRACT}

This study aimed to describe women's emancipation in fields of education, politics, family, and the professional sphere. Employing literary feminism approach as the theory and descriptive qualitative method, this research obtained data in the form of words, sentences, and paragraphs that reveals the presence of women's emancipation in the aforementioned fields from "Aku Lupa Bahwa Aku Perempuan" which is a novel by Ihsan Abdul Quddus as the data source. The data were collected through reading and recording technique to be analyzed later with the following techniques; identifying, classifying, analyzing, describing, interpreting, and concluding. The findings showed the following aspects: 1) women's emancipation in education was emphasized by the preference on education over marriage, opposing the dominance of men for the sake of education; 2) women's emancipation in the political sphere manifested itself in actions, such as posing women as a leader of the women, prioritizing politics, and striving for a political career; 3) women's emancipation in the family was manifested in the form of limiter removal of women's role, such as forcing the woman to be a mother and fighting for a career in the public sphere; 4) women's emancipation in the professional sphere was manifested in the form of disregard on women's role, putting aside personal interests, and struggling for women's rights; all for the sake of work.

Keywords: Emancipation, "Aku Lupa Bahwa Aku Perempuan”, Feminism

\section{Alamat Korespondensi:}

Prodi Pendidikan Bahasa dan Sastra Indonesia, Fakultas Sastra dan Budaya, Universitas Negeri Gorontalo Email: lilimaksum19@gmail.com; sancelamusu@ung.ac.id; herdi.ung@gmailcom 


\begin{abstract}
ABSTRAK
Penelitian ini bertujuan untuk mendeskripsikan emansipasi wanita bidang pendidikan, bidang politik, bidang keluarga, dan bidang pekerjaan. Teori yang digunakan dalam penelitian ini yaitu teori feminisme sastra. Metode penelitian ini adalah metode deskriptif kualitatif. Data yang diperoleh dalam penelitian ini adalah, katakata, kalimat, dan paragraf yang mengungkapkan adanya emansipasi wanita berupa emansipasi dalam bidang pendidikan, emansipasi bidang politik, emansipasi bidang keluarga, dan emansipasi bidang pekerjaan. Sumber data dalam penelitian ini adalah novel Aku Lupa Bahwa Aku Perempuan karya Ihsan Abdul Quddus. Teknik pengumpulan data menggunakan teknik baca dan teknik catat. Teknik analisis data yang dilakukan meliputi; mengidentifikasi, mengklasifikasikan, menganalisis, mendeskripsikan, menginterpretasi, dan menyimpulkan. Hasil penelitian ini menunjukan bahwa yang pertama, emansipasi wanita bidang pendidikan dalam novel Aku Lupa Bahwa Aku Perempuan adalah mengutamakan pendidikan dari pada menikah, melawan dominasi pria demi pendidikan; yang kedua, emansipasi bidang politik yang terwujud dalam tindakan yaitu menjadi pemimpin wanita, menomorsatukan politik, melakukan perlawanan demi karir politik; yang ketiga, emansipasi wanita bidang keluarga terwujud dalam bentuk tidak membatasi peran wanita, tidak membatasi peran wanita dengan menjadi ibu, melakukan perlawanan demi karir di ruang publik; yang keempat, emansipasi bidang pekerjaan terwujud dalam bentuk mengesampingkan peran wanita demi pekerjaan, mengesampingkan kepentingan pribadi demi pekerjaan, memperjuangan hak wanita demi pekerjaan.
\end{abstract}

Kata kunci: Emansipasi, novel Aku Lupa Bahwa Aku Perempuan, feminisme 


\section{PENDAHULUAN}

Karya sastra lahir dari sumber pengalaman sastrawan sendiri, baik dalam bentuk pengalaman lahiriah maupun pengalaman batiniah (Semi, 1988: 23). Berbicara tentang sastra tidak dapat terlepas dari berbicara tentang keindahan karena sastra adalah salah satu karya seni yang mengandung unsur keindahan. Salah satu karya sastra yang banyak mengandung unsur keindahan adalah novel.

Novel merupakan struktur yang bermakna. Pradopo (dalam Suguhastuti dan Suharto, 2005: 43) mengungkapkan bahwa novel tidak sekedar merupakan serangkaian tulisan yang menggairahkan ketika di baca, tetapi merupakan struktur yang tersusun dari unsur-unsur yang padu untuk mengetahui makna-makna atau pikiran tersebut. Di dalam novel terdapat unsur utama yang membangun utuhnya sebuah novel di antaranya, berupa tema, alur, latar, tokoh, penokohan, sudut pandang, gaya cerita, dan amanat. Namun, fokus penelitian ini adalah tokoh. Tokoh merupakan orang-orang yang berperan dalam sebuah cerita. Tokoh yang dimaksud dalam novel ini adalah tokoh wanita.

Perempuan selalu menarik untuk dibicarakan, tidak hanya menyangkut perempuan yang ada dalam kehidupan nyata, tetapi juga kehadiraanya di dalam karya sastra. Selain karena keindahan bentuk fisiknya, perhatian terhadap perempuan utamanya terkait dengan kehadirannya yang termarginalkan di ruang sosial budaya. Persoalan perempuan baik dari gaya hidupnya, cara berpakaian, ataupun kodrat sebagai seorang ibu yang melahirkan dan menyusui menjadi suatu pembahasan yang menarik. Setiap tokoh perempuan di dalam novel selalu diceritakan dari perspektif yang berbeda-beda, salah satunya pada novel $A k u$ Lupa Bahwa Aku Perempuan karya Ihsan Abdul Quddus yang menjadikan tokoh perempuan sebagai pusat penceritaan.

Kisah yang ditorehkan oleh Ihsan Abdul Quddus di dalam novel ini adalah untuk menuntut kesetaraan gender dan perjuangan melawan dominasi. Perempuan digambarkan seolah ingin mendobrak stereotip di masyarakat mengenai pemikiran bahwa perempuan identik dengan pekerjaan rumah tangga dengan segala sifat kefeminimannya, sedangkan laki-laki berperan di luar rumah sebagai sosok yang memimpin rumah tangga dan 
bertanggung jawab atas nafkah keluarga. Di sisi lain, realita yang berkembang di masyarakat mengenai ukuran ideal perempuan tetaplah mereka yang menghabiskan waktunya dalam pengabdian sepenuhnya untuk keluarga.

Potret perempuan sebagai makhluk nomor dua sepertinya menjadi stigma negatif kepada perempuan karena sejak awal sudah diposisikan sebagai makhluk nomor dua bahkan oleh kalangan ilmuan sekalipun. Namun, saat ini perempuan tidak hanya berperan di kasur dan di dapur. Perempuan bisa lebih dari itu. Perempuan bisa melakukan pekerjaan atau jabatan yang dipegang oleh laki-laki, sehingga hal inilah yang disebut sebagai gerakan emansipasi, yaitu memberikan kebebasan kepada perempuan.

Seiring dengan berkembangnya zaman, melalui gerakan emansipasi, perempuan akhirnya dapat menyejajarkan diri mereka dengan kaum pria dalam berbagai bidang kehidupan, baik dalam bidang politik, ekonomi, maupun sosial. Emansipasi wanita yang digambarkan dalam novel ini terdapat empat bidang yaitu, emansipasi wanita dalam bidang pendidikan, emansipasi wanita dalam bidang politik, emansipasi wanita dalam bidang keluarga, dan yang terakhir emansipasi wanita dalam bidang pekerjaan. Masing-masing emansipasi memiliki tujuan yang sama, yaitu untuk menyetarakan peran wanita dengan pria.

Kisah perempuan berhubungan erat dengan feminisme. Dasar pemikiran dalam penelitian sastra berperspektif feminisme adalah upaya pemahaman kedudukan dan peran perempuan seperti tercermin dalam karya sastra. Kedudukan dan peran para tokoh perempuan dalam karya sastra Indonesia menunjukan masih didominasi oleh laki-laki. Dengan demikian, upaya pemahamannya merupakan keharusan untuk mengetahui ketimpangan gender dalam karya sastra.

Teori feminisme sastra kemudian menjadi sebuah alat bedah yang dianggap cocok untuk dapat mengangkat kesetaraan perempuan dan laki-laki dari sisi pendidikan, politik, keluarga, dan pekerjaan. Harapan dengan menggunakan teori feminisme sastra dapat mengungkap kesetaraan kaum perempuan dan laki-laki yang diangkat dalam novel $A k u$ Lupa Bahwa Aku Perempuan karya Ihsan Abdul Quddus. 


\section{METODE PENELITIAN}

Pendekatan yang digunakan dalam penelitian ini adalah pendekatan deskriptif, yakni mendeskripsikan bentuk emansipasi wanita bidang pendidikan, emansipasi wanita bidang politik, emansipasi wanita bidang keluarga, dan emansipasi wanita bidang pekerjaan. Jenis penelitian yang digunakan dalam penelitian ini adalah kualitatif. Jenis penelitian ini digunakan untuk mengungkapkan gerakan emansipasi wanita dalam novel Aku Lupa Bahwa Aku Perempuan karya Ihsan Abdul Quddus. Oleh sebab itu, penelitian ini menggunakan teori feminisme sastra sebagai landasan teori untuk mengungkap gerakan emansipasi atau kesetaraan gender yang dilakukan oleh tokoh wanita.

Teknik pengumpulan data yang digunakan dalam penelitian ini adalah teknik baca dan teknik catat. Teknik baca yang digunakan dalam penelitian ini adalah teknik baca survey yang digunakan untuk membaca keseluruhan dari novel Aku Lupa Bahwa Aku Perempuan karya Ihsan Abdul Quddus. Sedangkan teknik catat dilakukan dengan cara mencatat kutipan-kutipan berupa narasi dan dialog antartokoh yang menggambarkan tindakan emansipasi dalam berbagai bidang, yaitu emansipasi bidang pendidikan, emansipasi bidang politik, emansipasi bidang keluarga, dan emansipasi bidang pekerjaan.

\section{HASIL PENELITIAN}

Pada bagian ini dideskripsikan data hasil penelitian, yaitu emansipasi wanita bidang pendidikan, emansipasi wanita bidang politik, emansipasi wanita bidang keluarga, dan emansipasi wanita bidang pekerjaan.

\section{Emansipasi Wanita Bidang Pendidikan}

Emansipasi wanita dikenal dengan suatu wujud dari perjuangan kaum wanita agar harkat dan martabat bisa sejajar dengan kaum pria. Emansipasi di Indonesia sendiri sudah lama diperjuangkan oleh kaum wanita. Pelopor kaum perempuan di Indonesia adalah R.A. Kartini. Dengan adanya gerakan emansipasi yang dipelopori oleh R.A Kertini tersebut, maka kaum wanita kini tidak lagi merasa tertindas atau berada di bawah kendali laki-laki. 
Pendidikan merupakan hal penting terutama bagi wanita, karena dengan adanya pendidikan yang diperoleh kaum wanita dapat mensejajarkan peran mereka dengan kaum pria. Pendidikan tinggi yang diperoleh kaum wanita adalah salah satu upaya untuk menerapkan gerakan emansipasi yaitu gerakan yang menuntut adanya kesetaraan gender. Sedangkan emansipasi memiliki arti yaitu suatu perwujudan untuk menyetarakan peran antara kaum pria dan wanita terutama dalam bidang pendididikan. Dengan adanya pendidikan bagi wanita, sekiranya mereka memiliki benteng yang kuat untuk tidak merasa tertindas oleh kaum pria.

Salah satu bentuk emansipasi yang ditampilkan dalam emansipasi wanita bidang pendidikan yaitu mengutamakan pendidikan terlebih dahulu daripada suatu pernikahan karena pendidikan sangat penting bagi wanita. Dengan memperoleh suatu pendidikan maka peran wanita akan sama dengan laki-laki. Seperti kutipan berikut.

"Sungguh, bila pada masa-masa itu kutemukan cinta, aku akan menikah meski belum selesai sekolahku. Tetapi saat itu aku tidak ditakdirkan untuk mencintai siapapun. Maka aku memutuskan untuk suatu saat nanti akan melangsungkan pernikahan yang memuaskan tuntutan nalarku. Nalarku mengatakan bahwa aku tidak akan menikah sebelum menamatkan pendidikan kesarjanaanku. Setelah tamat, baru aku akan memulaii tahapan untuk mimilih pasangan hidup". (Quddus, 2012: 16)

Berdasarkan pemaparan tersebut, emansipasi dalam bidang pendidikan ditunjukan oleh sikap Suad seperti pada kutipan "nalarku mengatakan bahwa aku tidak akan menikah sebelum menamatkan pendidikan kesarjanaanku". Hal tersebut menunjukan bahwa penolakan yang dilakukan oleh Suad untuk tidak menikah sebelum menamatkan pendidikan sarjananya menandakan bahwa pendidikan lebih penting dan pendidikan adalah hal utama yang harus diselesaikan terlebih dahulu sebelum dia memutuskan untuk menikah. Pendidikan juga adalah salah satu alat untuk membebaskan kaum wanita dari prakter pemarginalan dan pensubordinasian. Pendidikan merupakan sarana yang penting untuk mencapai kesetaraan antara laki-laki dan perempuan.

Wanita yang berpendidikan tidak akan mudah untuk didominasi oleh kaum laki-laki. Seperti yang kita tahu bahwa, ketika dalam rumah tangga namun wanita tidak mengenyam 
dunia pendidikan tentunya akan mendapatkan perlakukan yang kurang pantas dari kaum laki-laki, atau sering merendahkan kaum wanita. Maka dari itu, mengapa pendidikan sangat penting bagi kaum wanita, karena untuk membebaskan diri dari praktek pemarginalan yang menyiksa mereka.

"Sesaat kami saling diam. Pandangan mata kami bertaut. Kami melemparkan perasaan masing-masing kepada yang lain, seakan samasama membuat prediksi gerangan apa yang akan terjadi. Masih setengah berbisik hingga hampir tak terdengar, dia bertanya, "Bagaimana?"

Aku menggelengkan kepala dengan jawaban "ya" yang sengaja kusembunyikan. Sesaat aku termenung dan tiba-tiba aku ingin meralat gelengan kepalaku, "maksudku, kita tunda pembicaraan ini sampai aku selesai ujian skripsi." (Quddus, 2013: 24)

Menikah bukanlah hal yang tidak boleh, tetapi bagi Suad, menikah disaat usianya masih dalam masa menyelesaikan studi merupakan hal yang belum diinginkan. Suad adalah salah satu wanita yang banyak dikagumi oleh kamu laki-laki di kampusnya. Tetapi dia masih mengurungkan niatnya untuk memilih salah satu laki-laki yang nantinya akan dijadikan suaminya. Terbukti pada kutipan "kita tunda pembicaraan ini sampai aku selesai skripsi”. Hal ini menandakan bahwa sudah ada laki-laki yang ingin mempersunting dirinya namun Suad masih menolaknya. Penolakan tersebut bukan karena tidak suka, tetapi karena dia telah memiliki target tersendiri bahwa dirinya akan menikah setelah tamat dari bangku kuliah.

Sikap Suad yang menolak adanya pernikahan sebelum selesai dalam studinya menandakan bahwa adanya emansipasi dalam bidang pendidikan. Emansipasi ini memiliki arti bahwa wanita harus memperoleh pendidikan terlebih dahulu. Selain itu, pendidikan sangat penting bagi wanita, karena saat ini kedudukan perempuan masih rendah dimata laki-laki sehingga terjadi pensubordinasian pada kaum perempuan. Oleh karena itu, untuk mencapai kesetaraan peran antara laki-laki dan perempuan salah satunya mereka harus memiliki atau mengenyam pendidikan terlebih dahulu.

Wanita memiliki kodrat sebagai mahkluk yang lemah lembut sehingga membuat mereka selalu dipandang lemah oleh kaum laki-laki. Tetapi dengan adanya gerakan 
emansipasi yaitu upaya untuk menyetarakan peran antara laki-laki dan perempuan, wanita mulai melakukan perlawanan untuk memperoleh persamaan hak, terutama pada laki-laki yang selalu mendominasi. Seperti kutipan berikut.

"Perkawinan juga merupakan proses mendirikan bangunan. Kita berdua harus saling dukung dan membangun. Terus terang, kamu belum membantuku dalam mendirikan bangunanku. Aku juga mengakui belum banyak membantumu menemukan citramu. Aku sendiri sampai saat ini belum berhasil mendapatkan gelar doktorku..."

Abdul Hamid menimpali sambil meledekku, "Kamu telah mendapatkan Faizah. Dia lebih penting dan berharga daripada gelar doktor."

Aku Menghindar, "Aku memimpikan gelar doktor agar Faizah bangga dengan memilikiku. Bangga dengan ibunya yang doktor" (Quddus, 2013: 88).

Pernikahan merupakan salah satu cara untuk menyatukan dua kepribadian yang berbeda, yaitu dengan menjadi suami istri. Pernikahan juga harus bisa menyatukan dua pendapat yang berbeda dari kepala yang berbeda pula. Permasalahan yang sering timbul atau memacu adanya pertengkaran dalam rumah tangga biasanya dikarenakan tidak pernah saling mendukung dan membantu satu sama lain . Seperti yang tergambar pada data di atas. Suad dan Abdul Hamid, suaminya diterpa masalah rumah tangga yang begitu menyedihkan. Suad yang diceritakan selalu sibuk dengan urusan karir dan masalah politiknya, begitupun Abdul Hamid yang sama sekali tidak mendukung karir dan pekerjaannya menjadi suatu pemicu keretakan rumah tangga antara mereka berdua.

Suad adalah wanita yang penuh ambisi terhadap karir dan pekerjaannya, bahkan sampai melupakan dirinya sebagai seorang ibu. Tetapi wajar, wanita memang harus berkarir dan berpendidikan. karena dalam emansipasi bidang pendidikan dijelaskan bahwa salah satu cara untuk menuntut kesetaraan antara laki-laki dan perempuan adalah lewat pendidikan. Pendidikan itu sangat penting, terutama meningkatnya pendidikan pada wanita. Dengan pendidikan yang tinggi tidak sulit untuk menerapkan emansipasi wanita. Seperi yang dilakukan oleh tokoh Suad. Suad ingin menjadi wanita yang berpendidikan agar keberadaannya didalam keluarga tidak dipandang rendah oleh sang suami. Kemudian dia 
juga menginginkan agar anaknya bangga bahwa telah memiliki ibu. Bukan hanya sekedar ibu, tetapi ibu yang juga mempunyai gelar pendidikan yang tinggi yaitu doktor.

\section{Emansipasi Wanita Bidang Politik}

Marginalisasi bagi kaum perempuan masih sangat terasa dimasa saat ini. Pandangan bahwa kaum perempuan yang tidak layak untuk berkiprah pada dunia pekerjaan dan karir bahkan dalam kegiatan politik sekalipun seperti layaknya kaum laki-laki. Paradigma tersebut mengkristal pada pandangan sebagian besar masyarakat Indonesia.

Perempuan dan politik merupakan hal yang sulit dibayangkan, terutama di negaranegara berkembang. Hal ini dikarenakan telah terbentuk pemikiran oleh budaya patrilineal yang menjadikan peran perempaun hanya dibatasi pada urusan rumah tangga. Sedangkan politik yang digambarkan dengan kekuasaan selalu dikaitkan dengan laki-laki. Perempuan dianggap tabu terhadap kekuasaan dan kepemimpinan. Perempuan adalah makhluk rasional, kemampuannya sama dengan laki-laki, sehingga harus diberi hak yang sama seperti hak untuk masuk dan berkecimpung dalam dunia politik. Perjuangan emansipasi perempuan di dunia politik cukup mudah ditemui pada saat ini, karena cukup banyak wanita yang mulai bekerja di ranah politik.

Berbicara tentang dunia politik memang tidak akan pernah ada habisnya. Politik terus digerakan. Zaman sekarang wanita sudah memiliki peran yang sama dengan laki-laki seperti menjadi seorang pemimpin dalam demokrasi politik. Bukan saja laki-laki yang bisa bergerak dalam bidang politik, perempuan juga memiliki hak yang sama. Seperti yang tergambar pada kutipan di bawah ini.

"Aku masih remaja lima belas tahun ketika muncul gerakan nasionalisme Mesir untuk memerdekakan diri dari penjajahan Inggris. Aku merasa sekolahku harus ikut serta dalam gerakan revolusi ini. Akulah yang memotori gerakan-gerakan nasionalisme di sekolahku. Keesokan harinya aku kembali ke sekolah dan menggerakan teman-temanku untuk melakukan demonstrasi. Inilah demonstrasi pertama yang dilakukan oleh pelajar perempuan pada waktu itu. Aku melakukan lobi-lobi kecil dengan polisi dan mereka membiarkan kami melanjutkan demonstrasi hingga mendekati kampus universitas. Hari ini aku telah memiliki kemampuan 
untuk memobilisasi teman-temanku dalam gerakan demonstrasi".

(Quddus, 2012: 9-10)

Sikap Suad yang melakukan demonstrasi untuk membebaskan diri mereka dari penjajahan jepang merupakan salah satu gerakan emansipasi dalam bidang politik. Seperti yang tergambar pada kutipan, "akulah yang memotori gerakan-gerakan nasionalisme di sekolahku”. Kutipan tersebut membuktikan bahwa sikap Suad yang tidak terima dijajah sehingga melakukan perlawanan terhadap penjajahan seperti yang dilakukan oleh Inggris terhadap Mesir merupakan tindakan yang ingin mendapatkan keadilan. Oleh karena itu, Suad sebagai satu-satunya wanita yang ada di sekolahnya menjadi pemimpin demonstrasi pada waktu itu. Inilah demonstrasi pertama yang dilakukan oleh para pelajar perempuan.

Bukan hanya memotori teman-temannya dalam melakukan demonstrasi, tetapi Suad juga mampu melakukan lobi-lobi kecil dengan polisi. Sikap yang diambil oleh salah satu tokoh dalam novel ini yaitu tokoh yang bernama Suad merupakan sikap yang menandakan perempuan tidak hanya selalu dikaitkan dengan masalah rumah. Tetapi Suad sendiri membuktikan bahwa wanita juga bisa berkecimpung di dunia politik bahkan ikut dalam melakukan demonstrasi demi memerdekakan Mesir.

Data tersebut menandakan bahwa wanita bukanlah manusia yang lemah atau tidak bisa melakukan pekerjaan kaum laki-laki. Walaupun demonstrasi selalu identik dengan kaum laki-laki, tetapi terbukti bahwa salah satu tokoh yang ada pada novel ini yaitu Suad bisa melakukannya. Hal ini juga menunjukan bahwa wanita bukan hanya mengurus urusan rumah tangga, tetapi juga dapat berkecimpung dalam dunia perpolitikan, salah satunya melakukan demonstrasi. Bahkan negara Indonesia telah berkomitmen bahwa hak laki-laki dan perempuan dalam hal berpolitik itu sama.

Salah satu bentuk emansipasi yang ditemukan pada novel Aku Lupa Bahwa Aku Perempuan yaitu mengutamakan karir politik dari pada urusan pribadi. Seperti yang diketahui bahwa dunia politik sudah mulai melibatkan peran perempuan sama halnya dengan laki-laki. Untuk itu, tokoh Suad dalam novel ini diceritakan seolah-olah menyepelekan urusan pribadi demi berkarir di dunia politik. Berikut analisis di bawah ini. 
"Aku masuk dan duduk bersama mereka dalam penampilanku yang masih kacau. Ibunya melihatku dengan sinis kemudian berpaling ke anaknya seakan bertanya, "seperti inikah wanita yang kamu pilih untuk kau peristri?"

Abdul Hamid berkata kepadaku, "Kamu terlambat!"

Aku melemparkan pandangan protes kepadanya menekankan bahwa bukan haknya untuk mengaturku. Kulihat matanya dan kukirimkan pesan kedalam pandangannya bahwa lebih penting bagiku menyampaikan orasi politik di depan massa dari pada harus pulang dan bertemu dengannya. Aku berkilah, "Gerakan politik kali ini begitu dasyat. Aku sendiri tidak menyangka bahwa pengumuman perang ini benar-benar terjadi." (Quddus, 2013: 27)

Ungkapan tersebut menunjukkan Suad adalah wanita yang sangat menyukai dunia perpolitikan dan selalu melibatkan dirinya sebagai orang utama dalam segala kegiatan politik. Terbukti pada kutipan "lebih penting bagiku menyampaikan orasi politik di depan massa dari pada harus pulang dan bertemu dengannya”. Kutipan tersebut menandakan bahwa Suad lebih mementingkan orasi politiknya dibandingkan bertemua dengan Abdul Hamid. Sikap protes yang dilakukan oleh Suad adalah salah satu upaya gerakan emansipasi dalam bidang politik, dimana emansipasi dalam bidang ini memiliki arti bahwa wanita juga berhak untuk berkecimpung dalam dunia politik. Memang masih banyak di luar sana terutama kaum laki-laki yamg masih memandang rendah tentang kemampuan wanita di dunia politik. Tetapi zaman telah berubah, dengan adanya teori feminisme yaitu teori yang menuntut adanya kesetaraan gender, makin banyak wanita-wanita diluar sana yang mulai melakukan perubahan dan menentang argumen-armumen yang mengatakan bahwa wanita hanya bisa bekerja dalam rumah. Inilah salah satu sikap yang di lakukan Suad dalam novel ini, yakni dia melakukan perlawanan ataupun emansipasi untuk menyetarakan peran lakilaki dan perempuan terutama dalam bidang politik.

Suami adalah kepala keluarga dalam rumah tangga, dan bertugas untuk menafkahi istri dan anak. Tetapi bukan berarti laki-laki menyalahi peran dan kodrat yang mereka miliki, dan memandang rendah peran wanita. Wanita juga berhak menuntut adanya kesamaan hak dan berhak melakukan perlawanan ketika peran sebagai wanita sudah dipandang rendah oleh kaum laki-laki. Seperti pada kutipan berikut. 
"Lebih baik kamu memposisikan diri di depan pendukungmu sebagai pemilik konsep.

Aku menimpali, "Aku tidak butuh arahanmu dalam melakukan kampanyeku. Kamu tidak berkompeten untuk itu. Kamu tidak tau bagaimana memperlakukan pendukung. Dan membuktikan bahwa kamu belum memahamiku sepenuhnya hingga kini, saat kita sudah menjadi suami istri (Quddus, 2012: 161).

Suami yang memiliki seorang istri wanita karir dan aktif dalam dunia politik seharusnya mendukung dalam hal apapun. Termasuk dalam mengambil keputusan atau saat melakukan berbagai kegiatan yang menyangkut pekerjaan istri. Tetapi berbeda dengan Kamal yang memiliki sifat selalu bertolak belakang dengan Suad. Saat Suad sedang melakukan kegiatan politiknya, Kamal tidak pernah memahami Suad, terutama dalam hal pekerjaan. Mereka selalu terlibat pertengkaran hanya karna beda dalam mengemukakan pendapat. Tetapi Suad juga tidak pernah mau merasa rendah di depan Kamal. Dia selalu menampilkan dirinya sebagai seorang wanita yang juga mendominasi dalam rumah tangga. Tetapi bukan berarti Suad adalah istri yang tidak berbakti kepada suami, Suad hanya memperjuangkan haknya sebagai perempuan dan sebagai wanita karir. Seperti dalam emansipasi bidang politik yaitu semua warga negara berhak di dunia politik, termasuk perempuan. Perempuan tidak hanya melakukan pekerjaan domestik, tetapi perempuan juga memiliki hak yang sama dengan laki-laki, bahkan melakukan pekerjaan yang dilakukan oleh laki-laki yaitu menjadi pemimpin.

\section{Emansipasi Wanita Bidang Keluarga}

Setiap rumah tangga tentunya memiliki kepala rumah tangga. Laki-laki diibaratkan sebagai seorang pemimpin dalam rumah tangga yang memiliki seorang istri dan anak. Lakilaki dipandang sebagai seseorang yang memiliki kuasa terbesar dalam rumah tangga yang dipimpinnya. Sedangkan peran seorang wanita selalu dikaitkan dengan semua pekerjaan rumah tangga. Bahkan seorang istri tidak diperbolehkan untuk bekerja diluar rumah. Dalam novel ini, terdapat seorang tokoh wanita yang bernama Suad. Suad melakukan gerakan emansipasi untuk menuntut adanya kesetaraan gender, karena merasa kaum laki-laki terlalu mendominasi terutama dalam bidang keluarga. 
Kodrat sebagai wanita bukan menjadi batasan untuk tidak berkarir di luar rumah. Wanita bukan hanya dikaitkan dengan urusan domestik, tetapi wanita juga berhak untuk berperan diluar rumah yaitu bidang publik sama halnya dengan laki-laki. Seperti kutipan di bawah ini.

"Aku tidak menemukan bahwa keberadaanku sebagai wanita telah memberikanku batasan. Ini bukan berarti bahwa aku menolak untuk cantik atau pintar sebagaimana umumnya wanita. Aku hanya ingin menolak stigma tentang kecantikan dan kepintaran kaum wanita, yang hanya diperuntukan pada sisi ini dan terlarang untuk sisi itu. Buktinya, aku juga tidak menolak untuk menikah dan menjadi seorang ibu. Tetapi bagiku, perempuan tidak bisa dipenjarakan dalam jeruji pernikahan dan dibatasi perannya hanya menjadi seorang ibu. Perempuan bukan pembantu bagi suaminya, bukan pula pesuruh bagi anak-anaknya" (Quddus, 2012: 5).

Data tersebut mengindikasikan suatu bentuk emansipasi wanita dalam bidang keluarga, yang digambarkan langsung oleh tokoh Suad yang menurutnya peran wanita tidak bisa dibatasi hanya sebatas seorang ibu dan juga dibatasi oleh jeruji pernikahan. Pernikahan bukanlah salah satu alasan untuk tidak menjadi wanita yang sukses di mata publik. Buktinya Suad tidak menolak untuk menikah dan menjadikan dirinya sebagai seorang ibu. Suad tetap mengikuti perannya sebagai seorang wanita pada umumnya, namun dia menolak bahwa kecantikan dan kepintaran kaum wanita hanya di peruntukan pada sisi-sisi tertentu. Suad tidak ingin suatu saat nanti dia hanya dijadikan pembantu bagi suaminya dan pesuruh bagi anak-anaknya karena Suad sangat menjunjung tinggi adanya kesetaraan gender.

Berdasarkan sikap yang digambarkan oleh Suad tersebut jelas terlihat suatu tindakan emansipasi wanita dalam bidang keluarga. Kodrat sebagai wanita atau menjadi seorang ibu bukanlah halangan untuk tidak berperan di luar rumah. Wanita memang selalu dikaitkan dengan anggapan bahwa wanita itu sangat irasional dan emosional, sehingga perempuan tidak bisa tampil memimpin. Tetapi data tersebut menunjukan adanya perlawanan yang dilakukan oleh salah satu tokoh yang ada pada novel ini yaitu tokoh Suad, Seperti yang terlihat pada kutipan berikut "Tetapi bagiku, perempuan tidak bisa dipenjarakan dalam jeruji pernikahan dan dibatasi perannya hanya menjadi seorang ibu". Ungkapan tersebut menunjukan adanya gerakan emansipasi dalam bidang keluarga. 
Emansipasi dibidang keluarga memiliki arti bahwa peran wanita tidak hanya berkisar pada urusan rumah tangga yaitu mengurus anak, membersihkan dan membereskan rumah, ataupun urusan domestik lainnya. Bahkan pekerjaan wanita bisa dilakukan oleh laki-laki tanpa harus melimpahkan segala urusan rumah tangga kepada wanita. Wanita juga memiliki hak untuk berkarir di luar rumah dan tampil di depan publik dengan potensi mereka sendiri.

Peran wanita bukan hanya berkisar pada pekerjaan rumah atau domestik. Seperti membersihkan dan menata ruangan dalam rumah, mengurus anak, menyiapkan makanan untuk suami, dan masih banyak lagi. Hal itu memanglah kodrat wanita. Tetapi dengan adanya emansipasi yaitu upaya untuk menyetarakan peran wanita dan pria, maka wanita bisa menuntut hak mereka untuk sama dengan laki-laki yaitu berperan di luar rumah. Seperti pada kutipan di bawah ini.

"Bagaimana aku bisa mengatur rumah seluas ini dengan lima ruangan besar yang ada di dalamnya, sedangkan aku adalah wanita karir yang sibuk? Mungkin sampai saat ini belum ada wanita karir yang mampu menggabungkan tanggung jawab pekerjaan dan rumah tangga dengan porsi yang sama. Kebanyakan wanita karir melepaskan tanggung jawab rumah tangga untuk bisa bekerja dengan tenang. Begitu juga sebaliknya. Terdapat juga sebuah pola masyarakat bahwa seorang istri dengan karir pekerjaan di luar rumah hanya tinggal dalam rumah dengan satu atau dua kamar bersama suaminya. Bukan karena miskin melainkan sebuah pola hidup untuk mengurangi beban-beban rumah tangga sehingga bisa berkosentrasi dalam karir" (Quddus, 2012: 45).

Menjadi wanita yang harus fokus pada urusan rumah tangga tidaklah mudah bagi Suad yang sekarang sangat sibuk dengan pekerjaannya. Karirnya yang membuatnya tidak memiliki waktu untuk mengurus dan membersihkan rumahnya sendiri. Kebanyakan dari wanita-wanita yang memiliki pekerjaan yang padat sehari-harinya tidak dapat menggabungkan antara urusan dalam rumah dan pekerjaan di luar rumah. Bahkan Suad rela melepaskan urusan rumah tangga demi karir agar bisa bekerja dengan tenang tanpa harus memikirkan pekerjaan yang ada di dalam rumah. Suad memang wanita karir dan hariharinya sangat sibuk, bahkan dia tidak bisa mengatur dan menata peralatan rumahnya. Hal ini karena dirinya hanya memfokuskan pada karir dan pekerjaannya. 
Bentuk emansipasi dalam bidang keluarga dapat terlihat dari ungkapan Suad yaitu, "Bagaimana aku bisa mengatur rumah seluas ini dengan lima ruangan besar yang ada di dalamnya, sedangkan aku adalah wanita karir yang sibuk”. Ungkapan ini menjelaskan bahwa tidak semua wanita paham terhadap isi dan pekerjaan rumah. Buktinya Suad adalah wanita yang tidak mau menyerahkan seluruh dirinya pada urusan rumah tangga, kerena dia adalah wanita yang melakukan pekerjaan diluar rumah. Hal ini juga membuktikan bahwa tidak semua urusan rumah tangga selalu melibatkan seorang wanita, karena wanita juga berhak untuk berkarir di luar rumah dan melakukan pekerjaan yang sama halnya dengan laki-laki. Seperti yang dijelaskan dalam teori emansipasi dalam bidang keluarga bahwa, urusan rumah tangga bukan hanya menjadi tanggung jawab istri seorang, melainkan lakilakipun berhak mengambil bagian atau menyumbangkan setengah tenaga mereka dalam membantu untuk meringankan pekerjaan wanita yang ada di dalam rumah, termasuk juga dalam mengurus dan membesarkan anak.

Ketika peran wanita sudah disepelekan oleh kaum pria, maka wanita berhak melakukan perlawanan untuk memperoleh hak mereka terutama dalam hak untuk berkarir di luar rumah. Seperti pada kutipan berikut.

"Dari wajahnya tidak terlihat harapan dan rasa bangganya melihatku sukses menjadi wakil rakyat. Baginya, hiruk-pikuk pemilihan, organisasi pergerakan dan berbagai jabatan politis tidak lebih dari sebuah permainan yang diciptakan para penguasa untuk anak-anak kecil agar mereka diam dan menghentikan tangisannya. Ini semua berarti aku mustahil bisa mengendalikannya. Baginya, aku bukanlah seorang pemimpin... Tapi, tidak! ini tidak bisa dibiarkan. Aku harus mengendalikannya. "Aku menikah dengannya untuk mengendalikannya," batinku terus berteriak" (Quddus, 2012: 162).

Sebuah rumah tangga tentunya memiliki kepala rumah tangga yaitu suami. Suami bertugas untuk mencari nafkah dan membimbing istrinya. Tetapi bukan berarti seorang suami membatasi peran istrinya untuk mengembangkan potensi diri. Seperti yang tergambar pada kutipan tersebut, bahwa dokter Kamal tidak mendukung Suad karena Suad telah terpilih sebagai wakil rakyat. Bagi Kamal, Suad tidak pantas untuk menjadi seorang 
pemimpin wanita. Hal ini menandakan bahwa dokter Kamal tidak mendukung pencapaian seorang istri. Tetapi Suad bukanlah wanita biasa, dia tidak menyerah begitu saja. Walaupun Kamal tidak menyetujuinya, dia tidak berhenti dari jabatannya.

Suad adalah wanita yang akan memperjuangkan karirnya walau itu bertentangan dengan suaminya sendiri. Terbukti pada kutipan "Aku harus mengendalikannya. Aku menikah dengannya untuk mengendalikannya," batinku terus berteriak". Dari ungkapan tersebut, Suad berpikir bahwa dia harus mengendalikan Kamal, karena dia menikah dengan Kamal salah satu tujuannya yaitu bisa mengendalikannya dan mengikuti pola kehidupan Suad. Sikap yang digambarkan oleh Suad menandakan adanya gerakan emansipasi terutama dalam bidang keluarga yaitu, untuk menyetarakan peran perempuan dan laki-laki. Di dalam keluarga laki-laki memanglah kepala keluarga, tetapi bukan berarti wanita selalu mengikuti alur laki-laki dalam berpikir dan bertindak. Perempuan juga memiliki hak untuk bebas berekspresi di dunia publik.

\section{Emansipasi Wanita Bidang Pekerjaan}

Masyarakat memiliki pandangan bahwa perempuan adalah sosok yang harus bersifat feminis dan laki-laki harus bersifat maskulin. Sehingga diidentikkan dengan segala hal yang dianggap sisi feminis maupun maskulin sesuai konsep masyarakat pada umumnya dimana kaum wanita adalah sosok yang lemah lembut, tidak rasional dibandingkan dengan laki-laki dan tidak pantas memiliki karir yang setara dengan laki-laki. Anggapan bahwa semua pekerjaan rumah yang dianggap sepele dan dibebankan kepada perempuan masih banyak terjadi di masyarakat.

Seiring berkembangnya zaman, lahirlah gerakan emansipasi yang merupakan istilah yang dipakai sebagai bentuk pembebasan hak dan persamaan derajat antara laki-laki dan perempuan. Sehingga di era sekarang ini banyak perempuan yang sudah mulai bekerja di luar rumah (publik). Seperti yang digambarkan sosok wanita yang ada dalam novel ini yaitu Suad. Dia adalah salah satu wanita yang melakukan gerakan emansipasi untuk menyetarakan perannya dengan laki-laki di dunia pekerjaan. Emansipasi dalam bidang pekerjaan ditemukan ada tujuh data. Berikut akan dipaparkan hasil analisisnya. 
Peran wanita memang banyak dari pada peran laki-laki, seperti menjadi seorang ibu dalam mengurus pekerjaan rumah, mengurus anak, dan mengurus suami. Tetapi selain peran wanita dalam pekerjaan domestik, wanita juga berperan di luar rumah, salah satunya memiliki pekerjaan yang layak sama halnya dengan laki-laki. Seperti yang tergambar pada data berikut.

"Ini semua tidak mungkin kukorbankan hanya demi melakukan hal yang remeh: melahirkan anak. Tidak! tidak mungkin aku mengkhususkan diri mendidik anak dan meniggalkan berbagai peluang sukses yang sangat mungkin kuraih. Aku tau bahwa seorang anak membutuhkan waktu seluruh ibunya dan saat ini aku tidak memiliki waktu untuk menjadi ibu. Aku tidak ingin melantarkan anak demi karir atau melantarkan karir demi anak". (Quddus, 2012: 38)

Menjadi istri dan menjadi seorang ibu bukanlah perkara mudah dalam menjalani kehidupan berumah tangga. Terutama menjadi seorang ibu yang memiliki karir dan pekerjaan yang sangat padat. Ketika seorang wanita telah memiliki anak, maka waktu yang harus disediakanpun harus cukup. Karena seoarang anak akan mengalami pertumbuhan dan itu membutuhkan kehadiran seorang ibu untuk melatih tumbuh kembangnya seorang anak. Tetapi dalam novel ini digambarkan bahwa. Suad memiliki sifat yang bertolak belakang, atau bahkan berbanding terbalik dengan ibu-ibu di luar sana. Suad adalah sosok wanita yang selalu sibuk dengan karir dan pekerjaannya bahkan tidak memiliki waktu untuk mengurus anak dan suaminya. Terbukti pada data tersebut, sikap Suad dalam menolak dirinya untuk mempunyai anak semata karena dia tidak mau pekerjaan atau karirnya terganggu. Terlebih lagi dibuktikan oleh kutipan, "ini semua tidak mungkin ku korbankan hanya demi melakukan hal yang remeh: melahirkan anak". Suad mengatakan bahwa melahirkan anak adalah hal yang remeh, tetapi sesungguhnya bukan karena dia tidak mau memiliki anak, Suad menunda untuk memiliki anak agar dia terlebih dahulu harus mencapai targetnya untuk menjadi wanita yang sukses sebagai pemimpin.

Melalui ungkapan tersebut telah tergambar bahwa penolakan Suad dalam menunda untuk mepunyai seorang anak dan lebih memilih untuk berkarir di dunia pekerjaan merupakan salah satu gerakan emansipasi dalam bidang pekerjaan. Dimana dalam bidang 
ini dijelaskan bahwa perempuan bukan hanya bertugas mengurus urusan rumah tangga atau mengurus anak melainkan wanita juga berhak dalam mencari pekerjaan yang layak dan berkarir di dunia pekerjaan sama halnya dengan laki-laki. karena perempuan yang mempunyai bekal yang tinggi dan pemikiran tidak terbelakang bisa menyetarakan peran antara laki-laki dan perempuan. Oleh karena itu, Suad tidak mau dirinya hanya mengkhususkan untuk mengurus anak dan pekerjaan domestic lainnya. karena dia adalah wanita karir dan tidak mau terikat oleh peran sebagai seorang ibu.

Pekerjaan bagi wanita merupakan salah satu upaya untuk menyetarakan peran dengan laki-laki dalam bidang publik. Wanita bukan hanya pandai dalam urusan rumah tangga tetapi wanita juga harus pandai dalam memperoleh pekerjaan di luar rumah agar tidak dipandang rendah oleh kaum pria.

"Aku segera memotongnya, "Apa Anda bermaksud agar aku berhenti bekerja?"

Kamal menjelaskan dengan saksama, "Aku tidak bermaksud demikian. Aku hanya ingin agar kamu menciptakan suasana santai bagi hidupmu sendiri. Biarkan beberapa hari kamu memiliki dirimu sendiri di tempat yang membuatmu nyaman.

"Aku tidak terbiasa mengambil cuti. Aku tidak membutuhkannya," Aku membantah". (Quddus, 2012:138)

Hidup seorang diri dan selalu melakukan pekerjaan berhari-hari tanpa henti memang melelahkan bagi Suad, tetapi dia adalah sosok wanita yang kuat dan tidak mau mengorbankan pekerjaannya walaupun kadang dirinya merasakan lelah. Bahkan ketika dokter menyarankan untuk mengambil cuti untuk meringankan penyakitnya itu, Suad tidak mau. Baginya pekerjaan dan karirnya adalah separuh jiwanya, ketika dia tidak bekerja maka ada yang hilang dalam hidupnya. Suad sangat mencintai karir dan pekerjaannya, bahkan dia rela mengorbankan dirinya yang sedang sakit hanya demi pekerjaan dan tidak akan pernah mau untuk mengambil libur meski dalam keadaan sakit.

Seperti pada kutipan berikut "Aku tidak terbiasa mengambil cuti. Aku tidak membutuhkannya,". Sikap Suad yang menolak untuk mengambil cuti dan tetap bekerja, menandakan adanya emansipasi dalam bidang pekerjaan, dimana wanita haruslah memiliki pekerjaan. Karena wanita yang memiliki pekerjaan sendiri tidak akan dipandang rendah 
oleh kaum lelaki. Dalam dunia pekerjaan peran perempuan dan laki-laki sama, yaitu berhak pendapatkan pekerjaan yang layak. Seperti yang lakukan oleh Suad, walaupun dirinya sedang sakit tetapi hal itu bukanlah suatu halangan untuk tidak bekerja dan terus berkarir, karena baginya pekerjaan dan karir adalah hal yang utama.

Hak wanita dalam memperoleh pekerjaan yang sama dengan laki-laki merupakan salah satu upaya untuk menyetarakan peran wanita dan pria. Karena ketika wanita sudah memiliki pekerjaan maka perempuan tidak akan dipandang rendah oleh laki-laki.

"Jawabnnya datar, "yang kuinginkan dari dokter Suad adalah agar dia menampilkan dirinya, bukan jabatannya kepada orang-orang yang memberinya jabatan..."

Aku berusaha mengambil posisi, "Biarkan dokter Suad memilih dan menentukan apa yang dia inginkan. Aku akan menyampaikan pidato yang akan dilansir televisi dan surat kabar... Bukankah aku bebas melakukan pekerjaanku?" (Quddus, 2012: 204).

Istri memanglah memiliki kewajiban untuk patuh terhadap suami karena mereka adalah kepala keluarga dan bertanggung jawab untuk membimbing kita. Tetapi tidak semua perkataan maupun perbuatan yang harus kita patuhi kalau itu sudah melanggar dan membatasi peran kita sebagai seorang wanita. Wanita juga berhak untuk menolak dan melakukan perlawanan ketika perempuan sudah merasa tertindas bahkan ketika kaum lakilaki sudah mulai memandang remeh peran wannita. Seperti yang dialami oleh salah satu tokoh yang bernama Suad, Suami dari Suad yang bernama dokter Kamal melarang Suad untuk menjadi salah satu orang penting di dunia pekerjaan. Terbukti pada kutipan berikut "Bukankah aku bebas melakukan pekerjaanku?". Ungkapan ini menjelaskan bahwa perempuan berhak untuk melakukan pekerjaan, selama pekerjaan itu baik untuk mereka. Bahkan telah dijelaskan dalam teori emansipasi dlam bidang pekerjaan yaitu wanita memiliki peran yang sama dalam bidang pekerjaan, dan wanita juga berhak untuk menjadi seorang pemimpin layaknya seperti laki-laki. 


\section{PEMBAHASAN}

Berdasarkan hasil penelitian, ditemukan gerakan emansipasi wanita dalam novel $A k u$ Lupa Bahwa AKu Perempuan karya Ihsan Abdul Quddus terdiri dari emansipasi wanita bidang pendidikan, emansipasi wanita bidang politik, emansipasi wanita bidang keluarga, dan emansipasi wanita bidang pekerjaan.

Emansipasi wanita bidang pendidikan dalam novel Aku Lupa Bahwa Aku Perempuan dapat dilihat melalui tindakan tokoh wanita bernama Suad yang melakukan penolakan untuk menikah sebelum Ia lulus dari bangku kuliah dan mendapatkan gelar sarjana. Bentuk-bentuk emansipasi yang ditemukan dalam bidang pendidikan ini yang pertama, mengutamakan pendidikan dari pada menikah, yang kedua melawan dominasi pria demi pendidikan. Penolakan yang dilakukan oleh Suad merupakan suatu tindakan emansipasi wanita terutama dalam bidang pendidikan. Sesuai dengan pengertian emansipasi dalam bidang ini yang bahwa wanita yang memiliki pendidikan atau prestasi yang tinggi dapat menyetarakan perannya dengan kaum pria.

Emansipasi wanita bidang politik dalam novel Aku Lupa Bahwa Aku Perempuan terlihat melalui tindakan Suad mendominasi dalam kegiatan-kegiatan politik. Seperti yang kita tahu bahwa dunia politik selalu dikaitkan dengan pekerjaan laki-laki. Suad adalah sosok wanita yang sangat menekuni dunia politik, dan melakukan segala cara untuk melindungi karir politiknya termasuk menjadi salah satu pemimpin dalam orasi politik, selalu mengutamakan politik dari pada urusan pribadi, melindungi karir politiknya, dan melakukan perlawanan terhadap suami demi karir politik. Bentuk-bentuk emansipasi yang digambarkan oleh tokoh Suad merupakan salah satu upaya untuk penyetaraan gender dengan laki-laki terutama dalam dunia politik.

Emansipasi wanita bidang keluarga dalam novel Aku Lupa Bahwa Aku Perempuan terlihat melalui tindakan Suad yang melakukan perlawanan terhadap suami, ibu, bahkan masyarakat setempat yang masih memandang bahwa wanita itu hanya dapat berkecimpung dalam pekerjaan domestik. Suad digambarkan perannya tidak bisa dibatasi hanya dengan sebutan seorang ibu atau istri. Baginya laki-laki dan perempuan memiliki hak yang sama 
terutama dalam hal pekerjaan domestik terutama dalam hal mengurus anak dan mengurus pekerjaan rumah tangga. Dengan adanya emansipasi dalam bidang keluarga, maka wanita dapat melakukan penyetaraan gender dengan laki-laki dalam hal pekerjaan domestik.

Emansipasi wanita bidang pekerjaan dalam novel Aku Lupa Bahwa Aku Perempuan dapat dilihat oleh tindakan Suad yang menomorsatukan pekerjaan dibandingkan dengan urusan pribadi maupun kesenangan pribadinya. Suad adalah wanita yang lebih mementingkan karir dan pekerjaannya sampai-sampai dia lupa bahwa dia adalah seorang istri sekaligus ibu. Karena dengan adanya pekerjaan yang diperoleh seorang wanita maka peran mereka di dunia publik akan dipandang sama dengan laki-laki. Oleh karena itu, dengan adanya gerakan emansipasi wanita, semua wanita Indonesia dapat berkarir di dunia publik tanpa memandang rendah wanita dan mengatakan bahwa wanita hanya berhak bekerja dalam bidang domestik. Wanita dan pria memiliki hak yang sama dalam memperoleh pekerjaan.

\section{KESIMPULAN}

Berdasarkan hasil dan pembahasan mengenai emansipasi wanita dalam novel $A k u$ Lupa Bahwa Aku Perempuan karya Ihsan Abdul Quddus. Temuan dalam penelitian ini yaitu adanya gerakan emansipasi yang dilakukan oleh tokoh wanita yang bernama Suad. Emansipasi yang ditemukan terbagi menjadi emansipasi wanita bidang pendidikan, emansipasi bidang politik, emansipasi bidang keluarga dan emansipasi bidang pekerjaan. Peneliti mengklasifikasikan emansipasi berdasarkan teori feminisme yaitu teori yang memperjuangankan kesetaraan gender antara perempuan dan laki-laki baik dalam bidang pendidikan, politik, keluarga dan pekerjaan. 


\section{DAFTAR RUJUKAN}

Endraswara, Suwardi. Metodologi Penelitian Sastra. Yogyakarta: Media Pressindo. 2008.

Fakih, Mansour. Analisis Gender dan Transformasi Sosial. Yogyakarta: Pustaka Pelajar. 2013.

Hapma, Hamdi. "Emansipasi Wanita di Era Globalisasi dalam Perspektif Hukum Islan". Volume 8, No.2 (Juli, 2016).

Maleong Lexy J. Metodologi Penelitian Kualitatif. Bandung: PT Remaja Rosdakarya. 2001.

Semi, M. Atar. Anatomi Sastra. Padang: Angkasa Raya. 1988.

Siregar, Eliana. "Pemikiran Qasim Amin Tentang Emansipasi Wanita". Vol. VI No.2 (2016).

Sofia, Adib. Aplikasi Kritik Sastra Feminis: perempuan dalam karya-karya Kuntowijoyo. Yogyakarta: Citra Pustaka Yogyakarta. 2009.

Suguhastuti. Teori dan Apresiasi Sastra. Yogyakarya: Pustaka Pelajar. 2002. 